\section{Seedling Tolerance of Cool-season Turfgrasses to Metamifop}

\author{
Diego Gómez de Barreda ${ }^{1}$ \\ Universitat Politècnica de València, Camino de Vera s $/ n$, Edificio 3P, 46022 \\ Valencia, Spain
}

\author{
Jialin Yü and Patrick E. McCullough ${ }^{\mathbf{3}, \mathbf{4}}$ \\ University of Georgia, Crop and Soils, 1109 Experiment Street, Griffin, GA \\ 30223
}

Additional index words. establishment, herbicide, seed, turf management

\begin{abstract}
Grassy weeds may reduce cool-season turfgrass establishment after seeding and herbicide use is often warranted. Field experiments were conducted to evaluate the tolerance of creeping bentgrass (Agrostis stolonifera L.), perennial ryegrass (Lolium perenne $\mathrm{L}$.), and tall fescue (Festuca arundinacea Schreb.) to fenoxaprop and metamifop applications at 1, 2, 3, or 4 weeks after seeding (WAS). Creeping bentgrass groundcover was reduced from $34 \%$ to $71 \%$ at $8 \mathrm{WAS}$ from the nontreated by fenoxaprop at $50 \mathrm{~g}$ a.i./ha and metamifop at 400 and $800 \mathrm{~g}$ a.i./ha at all application timings. Metamifop at $200 \mathrm{~g} \cdot \mathrm{ha}^{-1}$ reduced creeping bentgrass cover $10 \%$ to $18 \%$ from the nontreated at 8 WAS when applied 1, 2, or 3 WAS, but treatments at 4 WAS did not reduce cover. Perennial ryegrass treated with fenoxaprop and metamifop at $800 \mathrm{~g} \cdot \mathrm{ha}^{-1}$ at $1 \mathrm{WAS}$ had cover reduced from the nontreated on two and one dates, respectively, whereas tall fescue cover was never reduced greater than $5 \%$ from the nontreated. Results suggest applications to creeping bentgrass should be delayed greater than 4 WAS for fenoxaprop at $50 \mathrm{~g} \cdot \mathrm{ha}^{-1}$, greater than 4 WAS for metamifop at 400 and $800 \mathrm{~g} \cdot \mathrm{ha}^{-1}$, and 3 WAS for metamifop at $200 \mathrm{~g} \cdot \mathrm{ha}^{-1}$. Additionally, fenoxaprop applications should be delayed 2 WAS for perennial ryegrass and tall fescue, whereas metamifop could be safely applied at all rates at 1 WAS.
\end{abstract}

In Georgia, cool-season grasses are primarily seeded in fall, rather than spring, to optimize establishment and minimize competition with warm-season annual grassy weeds. However, soil disruption, fertilization, and regular irrigation during establishment of cool-season grasses may promote crabgrass (Digitaria spp.) and goosegrass (Eleusine indica Gaertn.) germination in late summer or fall (Peters et al., 1989). Failure to control annual grassy weeds during establishment of cool-season grasses may lead to subsequent emergence of winter annual weeds such as annual bluegrass (Poa annua L.) that warrant further herbicide use and intensive management for successful culture.

Quinclorac effectively controls crabgrass and may be applied to seedling tall fescue at reduced labeled rates (less than $0.84 \mathrm{~kg}$ a.i./ha) but applications do not control goosegrass

Received for publication 25 June 2013. Accepted for publication 20 Aug. 2013.

We thank Bill Nutt, Seth Williams, and Bob Perry for technical support with this research. We also thank the PAID-00-12, I + D Programe from the Universitat Politècnica de València for supporting the sabbatical work of Diego Gómez de Barreda at the University of Georgia.

${ }^{1}$ Associate Professor.

${ }^{2}$ Graduate Assistant.

${ }^{3}$ Assistant Professor

${ }^{4}$ To whom reprint requests should be addressed; e-mailpmccull@uga.edu. and may cause excessive injury to creeping bentgrass and perennial ryegrass during establishment (Hart et al., 2004; McElroy and Breeden, 2007). Ethofumesate, mesotrione, and siduron are herbicides used during coolseason turf establishment but inconsistent efficacy, cost, and application regimens limit the effectiveness of these herbicides (Johnson, 1983; McElroy and Breeden, 2007; Moshier et al., 1976). Fenoxaprop is an aryloxyphenoxypropionate (AOPP) herbicide used in cool-season turf for controlling bermudagrass [Cynodon dactylon (L.) Pers.], crabgrass, and goosegrass but applications may injure perennial ryegrass, tall fescue, and other species during establishment (Dernoeden, 1987; Johnson and Carrow, 1993).

Metamifop is an AOPP herbicide used in rice (Oryza sativa L.) for post-control of grassy weeds (Hae-Jin et al., 2002). Compared with AOPP herbicides available in turf, creeping bentgrass has better tolerance to metamifop at rates required for weed control, whereas perennial ryegrass and tall fescue also have acceptable tolerance to applications (Carroll et al., 1992; Dernoeden, 1989; Flessner and McElroy, 2011; McElroy and Rose, 2009; Shim and Johnson, 1992). Metamifop could be useful for controlling annual grassy weeds after seeding cool-season grasses but turf tolerance during establishment has received limited investigation. The objective of this research was to evaluate application timing of metamifop, compared with fenoxaprop, on the establishment of creeping bentgrass, perennial ryegrass, and tall fescue grown from seed.

\section{Materials and Methods}

Field experiments were conducted in Griffin, GA, from Sept. 2011 to Mar. 2012 and Sept. 2012 to Feb. 2013. Plots in the second experiment were adjacent to the first experiments. Glyphosate was applied at $2.5 \mathrm{~kg}$ a.e./ha to mature tall fescue grown on a Cecil sandy clay loam (fine, kaolinitic, thermic Typic Kanhapludults) with pH 5.9 and 2\% organic matter in September of both years. Fields were scalped with a rotary mower, debris was removed, and soil was sliced in two directions at 1-cm depth. 'Penn A-4' creeping bentgrass, 'Manhattan V' perennial ryegrass, and 'Titan' tall fescue were seeded in 0.9-m strips at 49,392 , and $392 \mathrm{~kg} \cdot \mathrm{ha}^{-1}$ on 17 Oct. 2011 and 8 Oct. 2012. Creeping bentgrass seed was mixed with a $5 \mathrm{~N}-2 \mathrm{P}_{2} \mathrm{O}_{5}-0 \mathrm{~K}_{2} \mathrm{O}$ fertilizer at a 6:1 fertilizer:seed ratio to facilitate accuracy of the targeted seeding rate. Species were randomized in four replications, and fields were irrigated to promote turf establishment. Creeping bentgrass and perennial ryegrass were mowed at $1.3 \mathrm{~cm}$ with a reel-mower twice a week and tall fescue was mowed weekly at $6.3 \mathrm{~cm}$ with a rotary mower. The initial mowing began at $\approx 2.5$ weeks after seeding and clippings were returned.

Experimental design and treatments. Treatments were applied perpendicular to turf strips in a split-plot design where whole plots were species and subplots were herbicides. Treatments included fenoxaprop-p-ethyl (delineated fenoxaprop) at $50 \mathrm{~g}$ a.i./ha and metamifop at 200,400 , or $800 \mathrm{~g}$ a.i./ha. Applications were made at 1, 2, 3, or 4 weeks after seeding. Herbicide formulation, application dates, and turfgrass mowing heights during establishment are presented in tables. A nontreated control was included. Fenoxaprop was chosen as a standard comparison with metamifop at a recommended rate for annual weed control in most cool-season grasses (Anonymous, 2004). Applications were made with $\mathrm{CO}_{2}$-pressured sprayers calibrated to deliver $374 \mathrm{~L} \cdot \mathrm{ha}^{-1}$ with a single flat-fan nozzle (9504E flat-fan; TeeJet Spraying Systems) at $222 \mathrm{kPa}$.

Measurements and data analysis. Turfgrass cover was visually measured on a percent scale where 0 equals no turf cover and 100 equals complete plot cover. Cover was rated weekly from 2 to $8 \mathrm{WAS}$ and at $21 \mathrm{WAS}$. Grid counts were made for each species by counting the number of $161-\mathrm{cm}^{2}$ squares within a $0.58-\mathrm{m}^{2}$ grid (36 total squares per grid) with shoots present (yes/no) of the desirable turf species at 20 WAS in the 2012-13 experiment. Data were subjected to analysis of variance at the $0.05 P$ level. Species were analyzed separately as randomized complete blocks. Means were separated with Fisher's protected least significant difference test at $\alpha=0.05$. Year-by-treatment interactions were not detected, and thus, years were combined. 


\section{Results and Discussion}

Creeping bentgrass. Groundcover of nontreated creeping bentgrass increased from $42 \%$ at 2 WAS to $83 \%$ at 8 WAS (Table 1 ). All treatments applied 1, 2, or 3 WAS reduced creeping bentgrass cover from the nontreated from 4 to 8 WAS. Although metamifop at $200 \mathrm{~g} \cdot \mathrm{ha}^{-1}$ reduced cover at these timings, reductions from the nontreated ranged from $10 \%$ to $18 \%$ at $8 \mathrm{WAS}$, whereas 400 to 800 $\mathrm{g} \cdot \mathrm{ha}^{-1}$ reduced cover $35 \%$ to $71 \%$.

Metamifop treatments were generally less injurious to creeping bentgrass than fenoxaprop when applied 4 WAS (Table 1). Metamifop at 400 and $800 \mathrm{~g} \cdot \mathrm{ha}^{-1}$ and fenoxaprop applied 4 WAS reduced creeping bentgrass cover on three dates and measured $33 \%$ to $45 \%$ by 8 WAS. Creeping bentgrass cover was similar to the nontreated on all dates from metamifop at $200 \mathrm{~g} \cdot \mathrm{ha}^{-1}$ applied $4 \mathrm{WAS}$.

At 21 WAS, creeping bentgrass cover was similar to the nontreated from metamifop at $200 \mathrm{~g} \cdot \mathrm{ha}^{-1}$ applied at all timings after seeding, averaging $83 \%$ cover (Table 1 ). However, all other treatments reduced measurements from the nontreated, ranging from $23 \%$ to $64 \%$ cover. Reductions in creeping bentgrass groundcover were exacerbated by increased metamifop rate from 400 to $800 \mathrm{~g} \cdot \mathrm{ha}^{-1}$ at all timings, whereas fenoxaprop reduced cover more when applied 2, 3, and 4 WAS compared with 1 WAS.

Perennial ryegrass. Groundcover of nontreated perennial ryegrass increased from 2 to $8 \mathrm{WAS}$, ranging from $58 \%$ to $85 \%$ (Table 2 ). Fenoxaprop applied 1 WAS reduced perennial ryegrass cover at 2 and 3 WAS but was similar on other evaluation dates. Perennial ryegrass treated with metamifop at $800 \mathrm{~g} \cdot \mathrm{ha}^{-1}$ at 1 WAS reduced cover from the nontreated at 2 WAS but 200 and $400 \mathrm{~g} \cdot \mathrm{ha}^{-1}$ were similar on all dates. Fenoxaprop and metamifop at all rates applied 2, 3, and 4 WAS did not reduce perennial ryegrass cover from the nontreated on any date. Perennial ryegrass cover was similar to the nontreated at $21 \mathrm{WAS}$, averaging $88 \%$ across all treatments.

Tall fescue. Groundcover of nontreated tall fescue increased from 2 to 8 WAS ranging $39 \%$ to $84 \%$ (Table 3 ). Fenoxaprop and metamifop at 400 and $800 \mathrm{~g} \cdot \mathrm{ha}^{-1}$ applied 1 WAS reduced turf cover from the nontreated on one date but tall fescue recovered and was similar to the nontreated from 5 to 8 WAS. Treatments applied 2 WAS did not reduce turf cover from the nontreated except metamifop at $800 \mathrm{~g} \cdot \mathrm{ha}^{-1}$, which reduced cover $\approx 5 \%$ from the nontreated at 5 and 6 WAS. Tall fescue cover was similar to the nontreated at all evaluations from metamifop at all rates when applied 3 and 4 WAS. Fenoxaprop applied 3 WAS reduced tall fescue cover 5\% from the nontreated at 5 WAS. Cover was also reduced on all evaluation dates from metamifop applied at 4 WAS. However, reductions from the nontreated never exceeded $7 \%$ and would likely be considered acceptable in weed control programs during tall fescue establishment. There were no meaningful differences detected among treatments for tall fescue cover at 21 WAS, because all

Table 1. Groundcover of 'Penn A-4' creeping bentgrass treated with herbicides after seeding in two combined field experiments, 2011-13, Griffin, GA.

\begin{tabular}{|c|c|c|c|c|c|c|c|c|c|c|}
\hline \multirow[b]{2}{*}{ Timing $^{y}$} & \multirow[b]{3}{*}{ Treatment } & \multirow[b]{2}{*}{ Rate } & \multicolumn{8}{|c|}{ Creeping bentgrass cover (WAS) ${ }^{z}$} \\
\hline & & & 2 & 3 & 4 & 5 & 6 & 7 & 8 & 21 \\
\hline WAS & & $\overline{(\mathrm{g} \text { a.i./ha) }}$ & \multicolumn{8}{|c|}{ 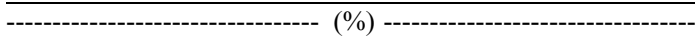 } \\
\hline \multirow[t]{4}{*}{1} & Fenoxaprop & 50 & 7 & 9 & 20 & 26 & 38 & 43 & 49 & 61 \\
\hline & Metamifop & 200 & 17 & 25 & 41 & 58 & 65 & 68 & 73 & 83 \\
\hline & & 400 & 12 & 15 & 22 & 31 & 38 & 43 & 48 & 62 \\
\hline & & 800 & 6 & 7 & 10 & 14 & 19 & 22 & 24 & 44 \\
\hline \multirow[t]{4}{*}{2} & Fenoxaprop & 50 & & 31 & 28 & 19 & 19 & 21 & 20 & 30 \\
\hline & Metamifop & 200 & & 43 & 47 & 53 & 59 & 62 & 66 & 79 \\
\hline & & 400 & & 33 & 31 & 25 & 26 & 28 & 31 & 48 \\
\hline & & 800 & & 29 & 22 & 14 & 11 & 12 & 13 & 23 \\
\hline \multirow[t]{4}{*}{3} & Fenoxaprop & 50 & & & 61 & 59 & 47 & 29 & 22 & 27 \\
\hline & Metamifop & 200 & & & 58 & 66 & 66 & 64 & 65 & 79 \\
\hline & & 400 & & & 62 & 60 & 43 & 35 & 35 & 62 \\
\hline & & 800 & & & 58 & 50 & 29 & 16 & 12 & 31 \\
\hline \multirow[t]{4}{*}{4} & Fenoxaprop & 50 & & & & 68 & 59 & 49 & 36 & 26 \\
\hline & Metamifop & 200 & & & & 78 & 77 & 75 & 75 & 88 \\
\hline & & 400 & & & & 74 & 69 & 59 & 45 & 64 \\
\hline & & 800 & & & & 74 & 67 & 53 & 33 & 30 \\
\hline \multirow[t]{2}{*}{ - } & Nontreated & 0 & 42 & 56 & 71 & 78 & 80 & 81 & 83 & 88 \\
\hline & & $\mathrm{LSD}_{0.05}$ & 7 & 8 & 9 & 10 & 11 & 10 & 8 & 12 \\
\hline
\end{tabular}

${ }^{\mathrm{z}} \mathrm{WAS}=$ week after seeding. Seeding dates were 17 Oct. 2011 and 8 Oct. 2012. Creeping bentgrass was mowed at 1.3-cm height with a reel mower $2 \mathrm{~d} /$ week.

${ }^{y}$ Fenoxaprop ( 0.57 EC) and metamifop (10\% EC) were applied on 24 Oct., 31 Oct., 7 Nov. 7 , and 14 Nov. in 2011 and 16 Oct., 23 Oct., 30 Oct., and 5 Nov. in 2012.

$\mathrm{LSD}=$ least significant difference; $\mathrm{EC}=$ electrical conductivity.

Table 2. Groundcover of 'Manhattan V' perennial ryegrass treated with herbicides after seeding in two combined field experiments, 2011-13, Griffin, GA.

\begin{tabular}{|c|c|c|c|c|c|c|c|c|c|c|}
\hline \multirow[b]{2}{*}{ Timing $^{\mathrm{y}}$} & \multirow[b]{3}{*}{ Treatment } & \multirow[b]{2}{*}{ Rate } & \multicolumn{8}{|c|}{ Perennial ryegrass cover (WAS) ${ }^{z}$} \\
\hline & & & 2 & 3 & 4 & 5 & 6 & 7 & 8 & 21 \\
\hline$\overline{\text { WAS }}$ & & $\overline{\text { (g a.i./ha) }}$ & \multicolumn{8}{|c|}{ 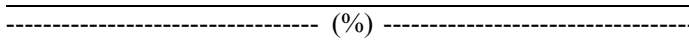 } \\
\hline \multirow[t]{4}{*}{1} & Fenoxaprop & 50 & 49 & 61 & 73 & 79 & 78 & 79 & 81 & 88 \\
\hline & Metamifop & 200 & 56 & 68 & 76 & 81 & 82 & 83 & 85 & 88 \\
\hline & & 400 & 55 & 67 & 78 & 81 & 81 & 83 & 85 & 89 \\
\hline & & 800 & 49 & 64 & 75 & 80 & 80 & 81 & 84 & 89 \\
\hline \multirow[t]{4}{*}{2} & Fenoxaprop & 50 & & 63 & 74 & 77 & 79 & 81 & 83 & 87 \\
\hline & Metamifop & 200 & & 72 & 81 & 84 & 84 & 84 & 86 & 91 \\
\hline & & 400 & & 68 & 76 & 82 & 81 & 83 & 86 & 90 \\
\hline & & 800 & & 65 & 74 & 77 & 77 & 80 & 81 & 88 \\
\hline \multirow[t]{4}{*}{3} & Fenoxaprop & 50 & & & 78 & 81 & 81 & 83 & 86 & 89 \\
\hline & Metamifop & 200 & & & 74 & 79 & 78 & 81 & 83 & 87 \\
\hline & & 400 & & & 77 & 81 & 81 & 81 & 83 & 91 \\
\hline & & 800 & & & 77 & 79 & 80 & 80 & 82 & 89 \\
\hline \multirow[t]{6}{*}{4} & Fenoxaprop & 50 & & & & 78 & 78 & 79 & 80 & 86 \\
\hline & Metamifop & 200 & & & & 83 & 83 & 83 & 85 & 88 \\
\hline & & 400 & & & & 83 & 82 & 82 & 84 & 89 \\
\hline & & 800 & & & & 80 & 83 & 80 & 81 & 86 \\
\hline & Nontreated & 0 & 58 & 68 & 77 & 81 & 80 & 83 & 85 & 89 \\
\hline & & $\mathrm{LSD}_{0.05}$ & 7 & 6 & 5 & 5 & 4 & 5 & 6 & 5 \\
\hline
\end{tabular}

${ }^{\mathrm{z}} \mathrm{WAS}=$ week after seeding. Seeding dates were 17 Oct. 2011 and 8 Oct. 2012. Perennial ryegrass was mowed at 1.3-cm height with a reel mower $2 \mathrm{~d} /$ week.

${ }^{y}$ Fenoxaprop ( 0.57 EC) and metamifop (10\% EC) were applied on 24 Oct., 31 Oct., 7 Nov., and 14 Nov. in 2011 and 16 Oct., 23 Oct., 30 Oct., and 5 Nov. in 2012.

$\mathrm{LSD}=$ least significant difference; $\mathrm{EC}=$ electrical conductivity.

plots had $8 \%$ or less difference from the nontreated.

Grid counts. Treatment-by-applicationtiming interaction was not detected for grid count measurements for any species, and thus, main effects are presented separately. For nontreated creeping bentgrass, $100 \%$ of grids had turf present at $20 \mathrm{WAS}$, whereas plots treated with metamifop at 200 and $400 \mathrm{~g} \cdot \mathrm{ha}^{-1}$ were similar (Table 4). However, fenoxaprop and metamifop at $800 \mathrm{~g} \cdot \mathrm{ha}^{-1}$ reduced the presence of creeping bentgrass in grid counts to $68 \%$ and $71 \%$, respectively. Treatments applied 2, 3, and 4 WAS reduced the presence of creeping bentgrass to $72 \%$ to $86 \%$ cover in grid counts but treatments 1 WAS were similar to the nontreated. Perennial ryegrass and tall fescue were present in all sampling grids across all treatments and application timings at $20 \mathrm{WAS}$.

Metamifop may have potential for use on perennial ryegrass and tall fescue seedlings, but reductions in creeping bentgrass cover may limit use to established turf only at rates tested. Although turf seedling tolerance to metamifop has received limited investigation, researchers have reported tolerance to other AOPP herbicides. For example, Dernoeden 
Table 3. Groundcover of 'Titan' tall fescue treated with herbicides after seeding in two combined field experiments, 2011-13, Griffin, GA.

\begin{tabular}{|c|c|c|c|c|c|c|c|c|c|c|}
\hline \multirow[b]{2}{*}{ Timing } & \multirow[b]{3}{*}{ Treatment $^{y}$} & \multirow[b]{2}{*}{ Rate } & \multicolumn{8}{|c|}{ Tall fescue cover (WAS) ${ }^{z}$} \\
\hline & & & 2 & 3 & 4 & 5 & 6 & 7 & 8 & 21 \\
\hline$\overline{\text { WAS }}$ & & $\overline{(\mathrm{g} \text { a.i./ha) }}$ & & $\cdots$ & --- & ---- & ---- & ---- & $---\cdot-$ & \\
\hline \multirow[t]{4}{*}{1} & Fenoxaprop & 50 & 32 & 48 & 65 & 76 & 78 & 82 & 85 & 88 \\
\hline & Metamifop & 200 & 41 & 56 & 69 & 79 & 81 & 83 & 85 & 86 \\
\hline & & 400 & 34 & 52 & 63 & 75 & 77 & 79 & 83 & 81 \\
\hline & & 800 & 36 & 51 & 68 & 77 & 79 & 83 & 85 & 89 \\
\hline \multirow[t]{4}{*}{2} & Fenoxaprop & 50 & & 50 & 66 & 76 & 78 & 81 & 83 & 88 \\
\hline & Metamifop & 200 & & 58 & 71 & 81 & 84 & 86 & 87 & 91 \\
\hline & & 400 & & 53 & 67 & 75 & 79 & 81 & 83 & 88 \\
\hline & & 800 & & 54 & 64 & 73 & 74 & 79 & 81 & 86 \\
\hline \multirow[t]{4}{*}{3} & Fenoxaprop & 50 & & & 66 & 74 & 76 & 79 & 82 & 87 \\
\hline & Metamifop & 200 & & & 66 & 76 & 78 & 79 & 82 & 86 \\
\hline & & 400 & & & 68 & 76 & 78 & 80 & 83 & 88 \\
\hline & & 800 & & & 70 & 78 & 78 & 79 & 81 & 87 \\
\hline \multirow[t]{6}{*}{4} & Fenoxaprop & 50 & & & & 74 & 74 & 76 & 78 & 83 \\
\hline & Metamifop & 200 & & & & 80 & 83 & 84 & 86 & 91 \\
\hline & & 400 & & & & 79 & 81 & 81 & 83 & 84 \\
\hline & & 800 & & & & 78 & 79 & 80 & 80 & 82 \\
\hline & Nontreated & 0 & 39 & 54 & 69 & 79 & 80 & 83 & 84 & 89 \\
\hline & & $\mathrm{LSD}_{0.05}$ & 5 & 6 & 6 & 5 & 5 & 5 & 4 & 5 \\
\hline
\end{tabular}

${ }^{2}$ WAS $=$ week after seeding. Seeding dates were 17 Oct. 2011 and 8 Oct. 2012. Tall fescue was mowed weekly at $6.3-\mathrm{cm}$ height with a rotary mower.

${ }^{y}$ Fenoxaprop ( 0.57 EC) and metamifop ( $10 \%$ EC) were applied on 24 Oct., 31 Oct., 7 Nov., and 14 Nov. in 2011 and 16 Oct., 23 Oct., 30 Oct., and 5 Nov. in 2012.

$\mathrm{LSD}=$ least significant difference; $\mathrm{EC}=$ electrical conductivity.

Table 4. Grid counts for turfgrass presence at 20 weeks after seeding 'Penn A-4' creeping bentgrass, 'Manhattan V' perennial ryegrass, and 'Titan' tall fescue treated with herbicides in a field experiment, Griffin, GA.

\begin{tabular}{|c|c|c|c|c|}
\hline \multirow[b]{3}{*}{ Herbicide } & \multirow{3}{*}{$\frac{\text { Rate }}{\text { (g a.i./ha) }}$} & \multicolumn{3}{|c|}{ Turfgrass presence $^{\mathrm{z}}$} \\
\hline & & Creeping bentgrass & Perennial ryegrass & Tall fescue \\
\hline & & \multicolumn{3}{|c|}{-- } \\
\hline Fenoxaprop & 50 & 68 & 100 & 100 \\
\hline \multirow{3}{*}{ Metamifop } & 200 & 100 & 100 & 100 \\
\hline & 400 & 87 & 100 & 100 \\
\hline & 800 & 71 & 100 & 100 \\
\hline \multirow[t]{2}{*}{ Nontreated } & 0 & 100 & 100 & 100 \\
\hline & $\operatorname{LSD}_{0.05}$ & 14 & NS & NS \\
\hline \multicolumn{5}{|c|}{ Application timing ${ }^{\mathrm{y}}(\mathrm{WAS})^{\mathrm{x}}$} \\
\hline & 0 & 100 & 100 & 100 \\
\hline & 1 & 96 & 100 & 100 \\
\hline & 2 & 72 & 100 & 100 \\
\hline & 3 & 86 & 100 & 100 \\
\hline & 4 & 73 & 100 & 100 \\
\hline & $\mathrm{LSD}_{0.05}$ & 14 & NS & NS \\
\hline
\end{tabular}

${ }^{{ }^{7}}$ Creeping bentgrass and perennial ryegrass were mowed at $1.3-\mathrm{cm}$ height with a reel mower $2 \mathrm{~d} /$ week. Tall fescue was mowed weekly at $6.3-\mathrm{cm}$ height with a rotary mower.

${ }^{y}$ Fenoxaprop $(0.57$ EC) and metamifop $(10 \%$ EC) were applied on 24 Oct., 31 Oct., 7 Nov., and 14 Nov. in 2011 and 16 Oct., 23 Oct., 30 Oct., and 5 Nov. in 2012.

${ }^{x} \mathrm{WAS}=$ week after seeding. Seeding dates were 17 Oct. 2011 and 8 Oct. 2012.

$\mathrm{LSD}=$ least significant difference; $\mathrm{NS}=$ nonsignificant; $\mathrm{EC}=$ electrical conductivity

(1987) noted perennial ryegrass and tall fescue seedlings were tolerant to fenoxaprop from 90 to $280 \mathrm{~g} \cdot \mathrm{ha}^{-1}$, and treatments effectively controlled smooth crabgrass (Digitaria ischaemum Schreb. Muhl.). In Georgia, Johnson and Carrow (1993) reported fenoxaprop temporarily injured tall fescue, but treatments did not reduce turfgrass density from the nontreated. In Virginia, Beam et al. (2005) noted fluazifop plus fenoxaprop treatments injured newly seeded tall fescue less than $5 \%$ at 5 weeks after initial treatment, suggesting applications have potential for grassy weed control during turf establishment.

Although AOPP herbicides are efficacious for grassy weed control, turf managers may also apply other chemistries in newly seeded creeping bentgrass, but metamifop may have comparable safety across these species. Flessner and McElroy (2011) reported singly or sequentially applied metamifop from 100 to $800 \mathrm{~g} \cdot \mathrm{ha}^{-1}$ caused minimal injury to established creeping bentgrass, kentucky bluegrass (Poa pratensis L.), and tall fescue. Fenoxaprop may be safely applied to mature perennial ryegrass and tall fescue at rates up to $200 \mathrm{~g} \cdot \mathrm{ha}^{-1}$, but researchers have reported significant injury (greater than 20\%) to established creeping bentgrass at lower rates (Carroll et al., 1992; Dernoeden, 1987, 1989; Johnson and Carrow, 1995; Neal et al., 1990). Shim and Johnson (1992) noted sequential applications of fenoxaprop at 70 to $200 \mathrm{~kg} \cdot \mathrm{ha}^{-1}$ caused unacceptable injury to creeping bentgrass, and turf did not fully recover after 3 months compared with nontreated. Henry and Hart (2004) reported creeping bentgrass density was reduced up to $33 \%$ from the nontreated after sequential applications of fenoxaprop at 40 or $70 \mathrm{~g} \cdot \mathrm{ha}^{-1}$, respectively.

Growth stage of grasses influences efficacy of AOPP herbicides, and treatments are often more phytotoxic when applied before tillering (Anderson, 1976; Derr et al., 1985; Wu and Santelman, 1976). Derr et al. (1985) reported goosegrass, large crabgrass (Digitaria sanguinalis L.), and giant foxtail (Setaria faberi Herrm.) control from fluazifop was substantially reduced when treatments were made at late tillering stages. Neal et al. (1990) noted fenoxaprop was less effective on tillered smooth crabgrass and large crabgrass compared with two to five leaf growth stages. Efficacy of AOPP herbicides may have important implications for cool-season turfgrass seedling tolerance, and further investigation is warranted to determine metamifop rates that are comparable to mesotrione, quinclorac, and other chemistries during establishment.

Overall, results suggest applications to creeping bentgrass should be delayed greater than 4 WAS for fenoxaprop at $50 \mathrm{~g} \cdot \mathrm{ha}^{-1}$, greater than 4 WAS for metamifop at 400 and $800 \mathrm{~g} \cdot \mathrm{ha}^{-1}$, and $3 \mathrm{WAS}$ for metamifop at $200 \mathrm{~g} \cdot \mathrm{ha}^{-1}$. Additionally, fenoxaprop applications should be delayed 2 WAS for perennial ryegrass and tall fescue, whereas metamifop could be safely applied at all rates at 1 WAS These recommendations are based on turfgrass maintained at mowing heights evaluated. Physiological effects of lower mowing height could potentially exacerbate turfgrass injury to these herbicides during establishment. Contrarily, higher mowing heights for grasses such as perennial ryegrass could increase seedling turfgrass tolerance to herbicides and warrant further investigation. Research is also needed to evaluate cool-season turfgrass seedling tolerance to multiple applications of metamifop alone and with other herbicides during establishment.

\section{Literature Cited} summer annual grasses with herbicides and the potential for enhancing turfgrass competition with other weeds in subsequent growing seasons.

Perennial ryegrass and tall fescue generally have greater tolerance to fenoxaprop than

Anderson, R.N. 1976. Control of volunteer corn and giant foxtail in soybean. Weed Sci. 24:253-256. Anonymous, 2004. Acclaim ${ }^{\circledR}$ Extra herbicide label. Bayer Environmental Sciences, Research Triangle Park, NC. 
Beam, J.B., W.L. Barker, and S.D. Askew. 2005. Italian ryegrass (Lolium multiflorum) control in newly seeded tall fescue. Weed Technol. 19:416-421.

Carroll, M.J., M.J. Mahoney, and P.H. Dernoeden. 1992. Creeping bentgrass quality as influenced by multiple low-rate applications of fenoxaprop. Weed Technol. 6:356-360.

Dernoeden, P. 1987. Tolerance of perennial ryegrass and tall fescue seedlings to fenoxaprop. Agron. J. 79:1035-1037.

Dernoeden, P. 1989. Mature creeping bentgrass and seedling kentucky bluegrass tolerance to fenoxaprop. Intl. Turf Res. J. 279-283.

Derr, J.F., T.J. Monaco, and T.J. Sheets. 1985. Response of three annual grasses to fluazifop. Weed Sci. 33:693-697.

Flessner, M. and J.S. McElroy. 2011. Potential use of metamifop for weed control in turfgrass. In: Annual meetings abstracts [CD ROM]. ASA, CSSA, and SSSA, Madison, WI.

Hae-Jin, C., H. Kim, H. Kim, S. Kim, D. Lee, J. Hur, and S. Kim. 2002. Postemergence weed control with a mixture of pyrazosulfuron and metamifop in rice (Oryza sativa L. cv. Tongjin). J. Agr. Sci. 13:89-96.

Hart, S.E., D.W. Lycan, and J.A. Murphy. 2004. Use of quinclorac for large crabgrass (Digitaria sanguinalis) control in newly summer-seeded creeping bentgrass (Agrostis stolonifera). Weed Technol. 18:375-379.

Henry, G.M. and S.E. Hart. 2004. Velvet and creeping bentgrass tolerance to fenoxaprop. HortScience 39:1768-1770.

Johnson, B.J. 1983. Response to ethofumesate of annual bluegrass (Poa annua) and overseeded bermudagrass (Cynodon dactylon). Weed Sci. 31:385-390

Johnson, B.J. and R.N. Carrow. 1993. Common bermudagrass control in tall fescue with fenoxaprop. Intl. Turfgrass Soc. Res. J. 7:303-309.

Johnson, B.J. and R.N. Carrow. 1995. Influence of fenoxaprop and ethofumesate treatments on suppression of common bermudagrass (Cynodon dactylon) in tall fescue (Festuca arundinacea) turf. Weed Technol. 9:789-793.

McElroy, J.S. and G.K. Breeden. 2007. Tolerance of turf-type tall fescue established from seed to postemergence applications of mesotrione and quinclorac. HortScience 48:382-385.

McElroy, J.S. and J.J. Rose. 2009. Creeping bentgrass and smooth crabgrass response to metamifop at two mowing heights. In: Annual meetings abstracts [CD ROM]. ASA, CSSA, and SSSA, Madison, WI.

Moshier, L., A.J. Turgeon, and D. Penner. 1976. Effects of glyphosate and siduron on turfgrass establishment. Weed Sci. 24:445-448.

Neal, J.C., P.C. Bhowmik, and A.F. Senesac. 1990. Factor influencing fenoxaprop efficacy in cool-season turfgrass. Weed Technol. 4:272278.

Peters, T.J., R.S. Moomaw, and A.R. Martin. 1989. Herbicides for postemergence control of annual grass weeds in seedling forage grasses. Weed Sci. 37:375-379.

Shim, S.R. and B.J. Johnson. 1992. Response of creeping bentgrass to spring-applied herbicides. HortScience 27:237-239.

Wu, C.-H. and P.W. Santelman. 1976. Phytotoxicity and soil activity of HOE- 23408. Weed Sci. 24:601-604. 